\title{
Evidence of paleoearthquakes from trench investigations across Pinjore Garden fault in Pinjore Dun, NW Himalaya
}

\author{
Javed N Malik ${ }^{1}$ and George Mathew ${ }^{2}$ \\ ${ }^{1}$ Department of Civil Engineering, Indian Institute of Technology Kanpur, Kanpur 208016. \\ e-mail: javed@iitk.ac.in \\ ${ }^{2}$ Department of Earth Sciences, Indian Institute of Technology Bombay, Powai, Mumbai 400076. \\ e-mail: gmathew@iitb.ac.in
}

The Pinjore Garden Fault (PGF) striking NNW-SSE is now considered one of the active faults displacing the younger Quaternary surfaces in the piggyback basin of Pinjore Dun. This has displaced the older Kalka and Pinjore surfaces, along with the other younger surfaces giving rise to WSW and SW-facing fault scarps with heights ranging from 2 to $16 \mathrm{~m}$. The PGF represents a younger branch of the Main Boundary Thrust (MBT) system. An $\sim 4 \mathrm{~m}$ wide trench excavated across the PGF has revealed displacement of younger Quaternary deposits along a low angle thrust fault. Either side of the trench-walls reveals contrasting slip-related deformation of lithounits. The northern wall shows displacement of lithounits along a low-angle thrust fault, while the southern wall shows well-developed fault-related folding of thick sand unit. The sudden change in the deformational features on the southern wall is an evidence of the changing fault geometry within a short distance. Out of five prominent lithounits identified in the trench, the lower four units show displacement along a single fault. The basal unit 'A' shows maximum displacement of about $T_{o}=2.85 \mathrm{~m}$, unit $\mathrm{B}=1.8 \mathrm{~m}$ and unit $\mathrm{C}=1.45 \mathrm{~m}$. The displacement measured between the sedimentary units and retro-deformation of trench log suggests that at least two earthquake events have occurred along the PGF. The units A and D mark the event horizons. Considering the average amount of displacement during one single event $(2 \mathrm{~m})$ and the minimum length of the fault trace $(\sim 45 \mathrm{~km})$, the behaviour of PGF seems similar to that of the Himalayan Frontal Fault (HFF) and appears capable of producing large magnitude earthquakes.

\section{Introduction}

Identification and mapping of active faults and deciphering their seismic potential are of vital importance in a seismically active region. The Himalayan region is one of the best known examples worldwide for its seismic potential and for understanding active compression-related deformation. The ongoing crustal deformation in the region is well reflected in the occurrence of small, medium and large-magnitude earthquakes along the Himalayan arc. The most prominent largemagnitude events that have struck the Himalayan foothill zones during the recent past are the 1897
Shillong (Ms 8.7), 1905 Kangra (Ms 7.8), 1934 Bihar (Ms 8.4) and 1950 Upper Assam (Ms 8.5) earthquakes (Seeber and Armbruster 1981; Yeats et al 1997; Ambraseys and Bilham 2000) (figure 1). The great Himalayan earthquakes are the largest known to have occurred on intercontinental thrust faults. These activities were, however, not accompanied by any coseismic surface rupture (Yeats et al 1997). On the basis of available seismological information, some areas in the Himalaya have been categorized as seismic gaps (Khattri and Tyagi 1983), and are believed to have the highest probability for one or more large magnitude $(M>8)$ earthquakes in the future (Bilham et al

Keywords. Pinjore; Himalaya; active faults; paleoearthquakes; trench. 


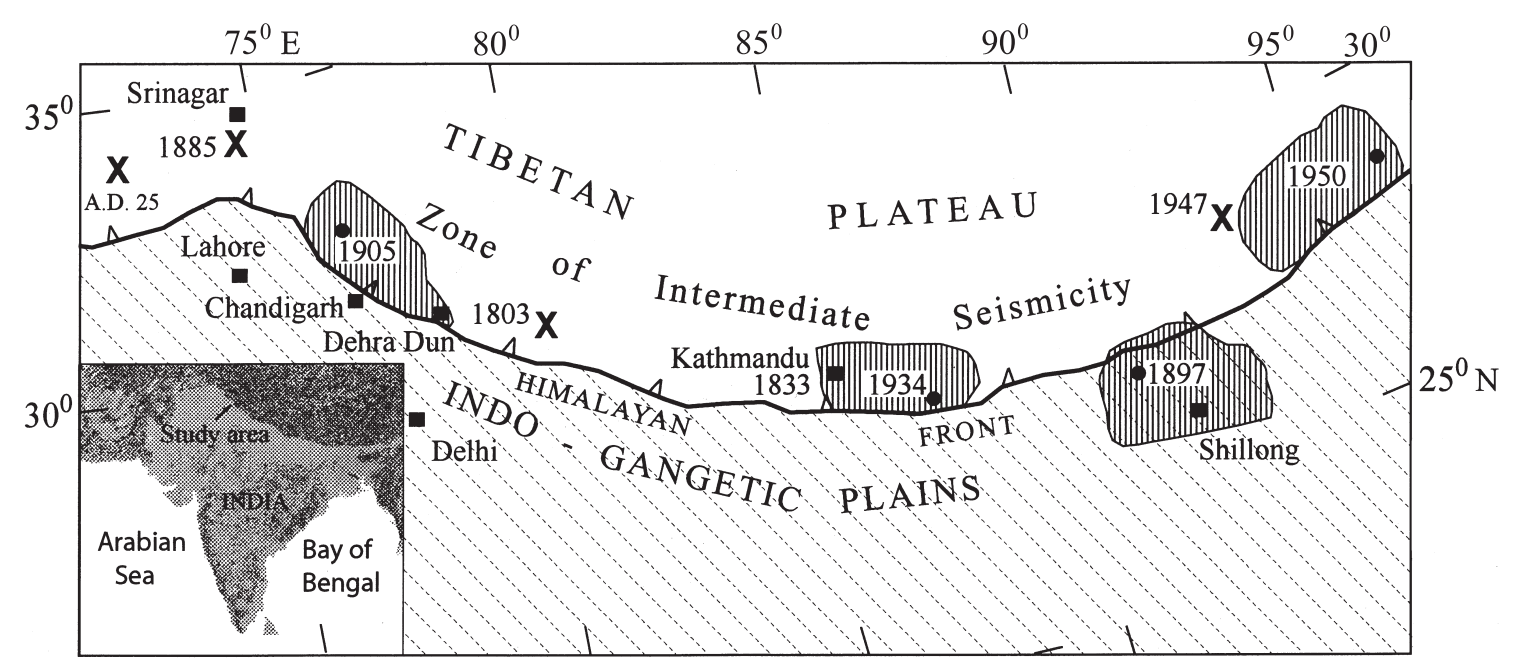

Figure 1. Map showing meizoseismal zones of four great earthquakes along the Himalayan front and other large magnitude events (after Yeats and Thakur 1998). Inset shows a map of India with the location of the study area.

2001). This is essentially because less than $45 \%$ of the Himalayan arc has been ruptured during the major earthquakes in the last 200 years (Valdiya 2001). The average slip associated with these major events seems to be only a few meters, but those areas where past events have already released much of the accumulated strain have little likelihood for yet another release of strain energy resulting in a major event (Bilham et al 1998).

There have not been many paleoseismological studies carried out specifically to identify the presence of active faults in this region, and to understand their potential to produce a large magnitude event. Further, data regarding the recurrence period of large events along individual faults that have displaced late Pleistocene and Holocene surfaces are also lacking. Fault scarps all along the active faults are clear manifestations of the ongoing active deformation (Malik and Nakata 2003; Malik et al 2003). Recent paleoseismic studies (Kumar et al 2001), on the Black Mango tear fault on the Himalayan Frontal Fault (HFF) has provided evidences of two large surface ruptures during the past 700 years; subsequent to $1294 \mathrm{AD}$ and 1423 $\mathrm{AD}$, and possibly another rupture at about 260 AD. This fault indicated a slip and crustal shortening of $9.62_{-3.5}^{+7.0} \mathrm{~mm} /$ year and $8.42_{-3.6}^{+7.0} \mathrm{~mm} /$ year respectively. Similarly, paleoseismic investigations by Malik and Nakata (2003) and Malik et al (2003), along one of the younger branching-out faults of the HFF system have revealed evidence of a large magnitude paleoearthquake, and a slip rate of about $6.3 \pm 2 \mathrm{~mm} / \mathrm{yr}$, horizontal shortening of $5.8 \pm 1.8 \mathrm{~mm} / \mathrm{yr}$ and recurrence interval of $555 \pm 118$ years. The luminescence dates indicate that the event occurred around $600 \mathrm{yr}$ B.P. (Malik et al, under preparation). On the basis of two colluvial wedges observed in a trench excavated across the Sirmurital fault in Dehra Dun valley, Oatney et al (2001) also suggested that large magnitude earthquakes have struck this region in the last 1000 years.

In the present paper, we document the preliminary paleoseismological investigation results that provide evidence of two large magnitude paleoearthquake events in the Pinjore Dun, along one of the imbricate faults of the MBT system called the 'Pinjore Garden Fault' (PGF) (figures 2 and 3). The Pinjore town in Pinjore Dun is a well known religious and historical place. It is widely believed that the Pandavas of Mahabharata stayed in the area during their exile. The place was then known as Panchpura, and later changed to Pinjore. Remnants of the ancient culture are evident in this region, consisting of numerous sculptures and other antiquarian remains dating back to 9th-12th century AD, and the Mughal culture (Mughal Garden) which dates back to 17th century AD.

\section{Geomorphic and tectonic setting}

The terrain around the study area can be divided into four major geomorphic zones (figure 2), from north to south;

- uplands comprising Lower Siwalik/Lower Tertiary rocks of the Dagshai, Kasauli and Subathu Formations,

- longitudinal alluvial fill-depression, the Pinjore Dun,

- isolated Upper Siwalik frontal range, and

- Indo-Gangetic plains. 


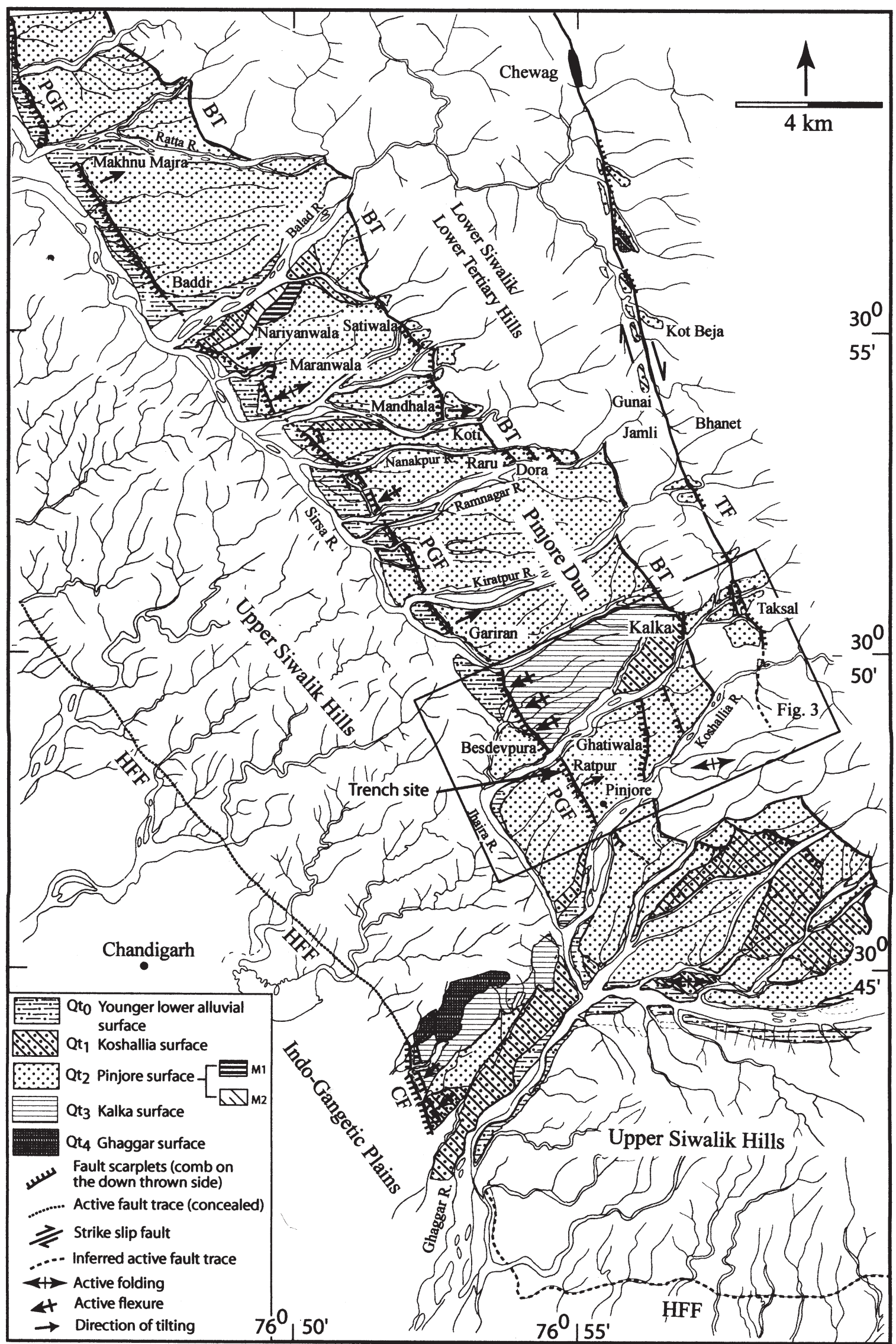

Figure 2. Distribution of active fault traces and terraces along northwestern Himalayan foothill zone around Chandigarh and Pinjore Dun. CF - Chandigarh fault; HFF - Himalayan Frontal fault; PGF - Pinjore Garden fault; BT - Barsar thrust and TF - Taksal fault. Combs on the active faults indicate down thrown side (after Malik and Nakata 2003). 
Pinjore Dun is a typical 'piggyback basin'. It has been argued (Ori and Frined 1984; Burbank and Reynolds 1988) that the propagation of thrust fronts into the foreland caused numerous structural and depositional changes leading to the development of new 'piggyback' basins behind the thrusts. The Pinjore Dun is 8 to $10 \mathrm{~km}$ wide, trending parallel to sub-himalayan ranges to its north and Lower Siwalik/Lower Tertiary hills to the south with altitudes ranging from 600 to $1600 \mathrm{~m}$ in the northeast and hogback ridges of Upper Siwalik hills with altitudes of 400 to $600 \mathrm{~m}$ in the southwest (figure 2). The Dun is about $45 \mathrm{~km}$ in length, merging farther north with the Son Dun. It consists of alluvial-fill of late Pleistocene to Holocene age overlying the Middle and Lower Siwalik succession. These sediments represent debris deposits of coalesced alluvial fans that were brought down by the Himalayan rivers along with fine-grained fluvial and lacustrine deposits. The morphology of the various alluvial fan and fluvial surfaces suggests that initially the Pinjore valley was aggraded under an alluvial-fan environment. The fan aggradation continued until the stream flows were unconfined. Later, channelised flows caused incision of the alluvial-fan surfaces and contemporaneous aggradation within the confined riverbanks resulting in the formation of terraces at different levels all along their course. It is, however, difficult to decouple the respective roles of climate and tectonics that were responsible for the formation of these terraces, but the role of tectonics seems to be the dominant factor in creating highly incised banks, where the rivers cross the fault trace. It has been envisaged (Nakata 1989; Malik and Nakata 2003) that these terraces/ surfaces were dislocated along several fault lines resulting in prominent scarps in Pinjore Dun. On the basis of the degree of dissection and level of distribution, five levels of terraces were observed in the Pinjore Dun and along the Ghaggar river. These are, from oldest to youngest, the Ghaggar Surface, Kalka Surface, Pinjore Surface, Koshallia Surface and the younger alluvial Surface (Nakata 1989; Malik and Nakata 2003) (figure 2).

An active fault running across the Pinjore Dun has vertically displaced and back-tilted various surfaces (figures 2 and 3 ). The traces of this fault are observed only as segments belonging to a single system that extends laterally for more than $45 \mathrm{~km}$ NNW-SSE. This fault was named the 'Pinjore Garden Fault' (PGF) by Malik and Nakata (2003). It is well exposed between Pinjore and Baddi towns, along the Pinjore-Nalagarh State Highway. Apart from the PGF, two locally developed active fault traces $\sim 2 \mathrm{~km}$ in length were identified east of Pinjore town, striking N-S and NNW-SSE near Ghatiwala and Ramsar villages respectively (figures 2 and 3 ). These faults are confined between the Koshallia and Jhajra rivers and have displaced the Pinjore surface resulting in a west-facing tectonic escarpment. The PGF is located about $10 \mathrm{~km}$ north of the HFF and therefore, is an important fault segment to understand foreland migration between the MBT and HFF.

The PGF has displaced the older Kalka Surface and Pinjore Surface along with the younger surfaces giving rise to WSW and SW-facing fault escarpments. The height of the fault scarps ranges from 2 to $16 \mathrm{~m}$. Around Pinjore town the active fault striking $\mathrm{N} 35^{\circ} \mathrm{W}$ passes through the Mughal Garden located between the Koshallia and Jhajra rivers, where the $12 \mathrm{~m}$ high 'Big Step' marks the fault scarp (figure 3). The garden was constructed in $\sim 1600 \mathrm{AD}$. The $12 \mathrm{~m}$ high natural fault scarp (big/main step) is used as the 'main step' consisting of several steps leading to the lower reaches of the garden (figures 3 and 4). It is also used as waterway in the central portion, longitudinally across the garden. The height of the scarp is not uniform. To the south of Mughal Garden, it is 8 to $10 \mathrm{~m}$ and the fault extends further south to village Isharnagar on the left bank of Koshallia river. Towards the north of the garden, its height is 1.5 to $2 \mathrm{~m}$. Further north, the scarp along the active fault trace striking NNW-SSE passes through the Pinjore town with a variable height ranging from 6 to $12 \mathrm{~m}$. Such variations in fault scarp heights are due to either changes in the amount of slip along the fault or variations associated with the geometry of faulting and lithology of faulted material (Philip et al 1992; McCalpin 1996). We suggest that the variation of scarp height along PGF is probably related to changes in the slip amount and the dip of fault along its strike. However, the $\sim 16 \mathrm{~m}$ high scarp of the Kalka surface suggests that this older surface has been dislocated several times along the PGF during episodic uplift as compared to the Pinjore Surface.

At Ratpur village, the PGF has displaced the Pinjore surface resulting in a $6 \mathrm{~m}$ high west-facing scarp (figures 5 and 6). Based on the degree of dissection of the surface, it appears that this scarp is quite young (late Holocene?) and has preserved the youngest movement along the fault. The Jhajra river channel flowing transverse to the fault trace shows distinct incision near the fault line where it crosses the uplift, whereas less incision is observed along its downstream reaches. This indicates that the changes in the local base-level of the channel floor have resulted in a larger amount of downcutting, as the river crosses the uplifted portion along the fault. Symmetrical incision has been observed on both the banks of the Jhajra river. Slight back-tilting (angle $6^{\circ}-10^{\circ}$ ) of the displaced surface towards northeast was noticed at Ratpur. Further 


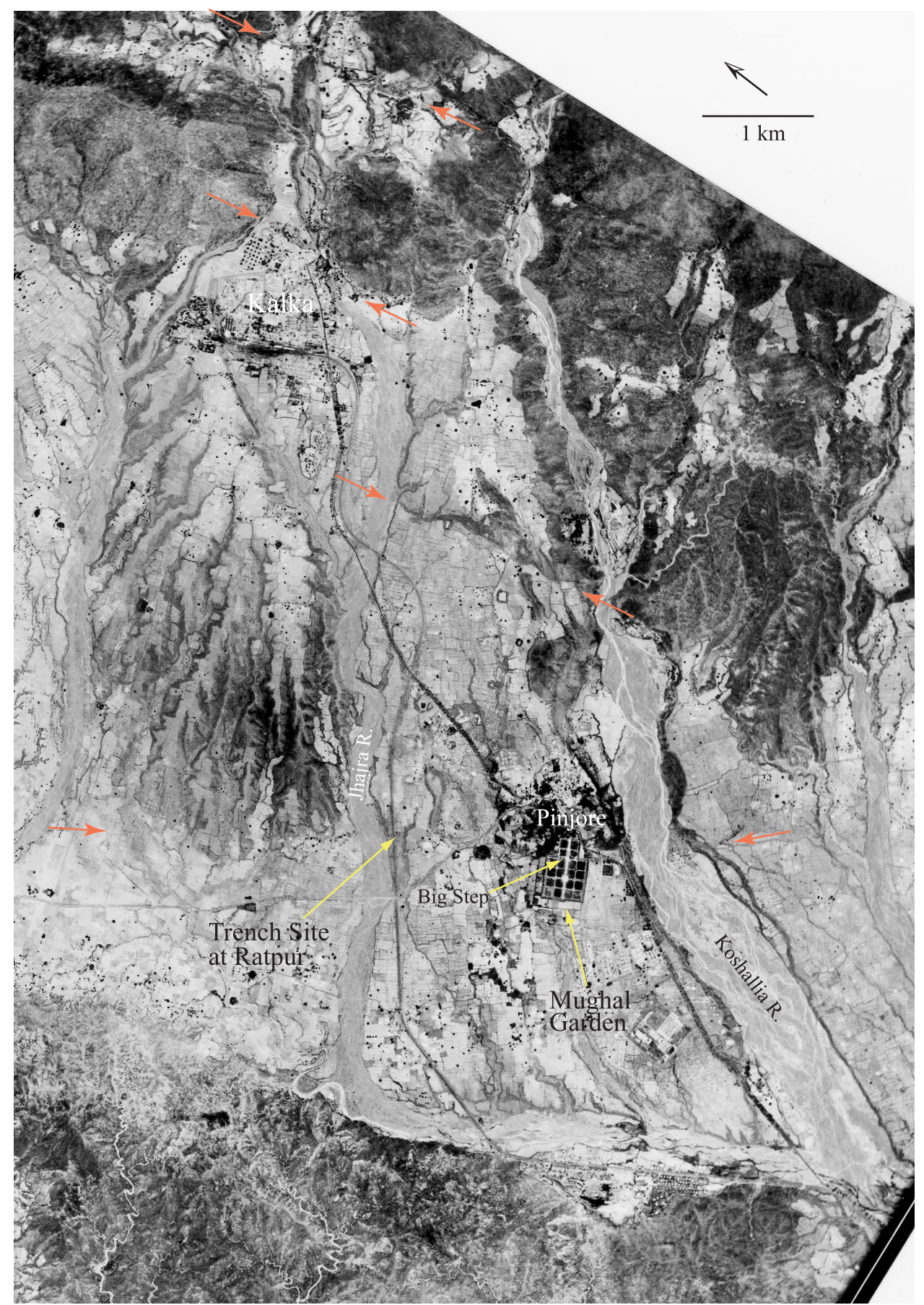

Figure 3. Satellite photos showing active fault traces cutting across the Pinjore Dun and along the Lower Siwalik range front (refer to figure 2 for location). The active faults are marked by arrows. The PGF trending $\mathrm{N} 25^{\circ} \mathrm{W}$ passes through the Mughal Garden. Location of trench site and 'Big Step' in Mughal Garden (fault scarp) is indicated by arrows.

north along the fault trace, prominent back-tilting was observed near villages Gariran, Maranwalal, Nariyanwala and Makhu-Majra (figures 2 and 7). To the north of Ratpur, the fault passes through the village Basdevpura, uplifting and warping the Kalka surface in between the Jhajra and Sirsa rivers. This Kalka Surface is presently marked by intensive gully erosion (figure 3 ).
The displacement pattern along the PGF is represented by active fault scarps developed on the older (Kalka) as well as younger (Pinjore) surfaces, indicating that this fault system has remained active ever since it formed. Back-tilting and warping of the surfaces near the fault line are further evidence of movement along a low-angle thrust fault dipping northeast. The Pinjore Garden 


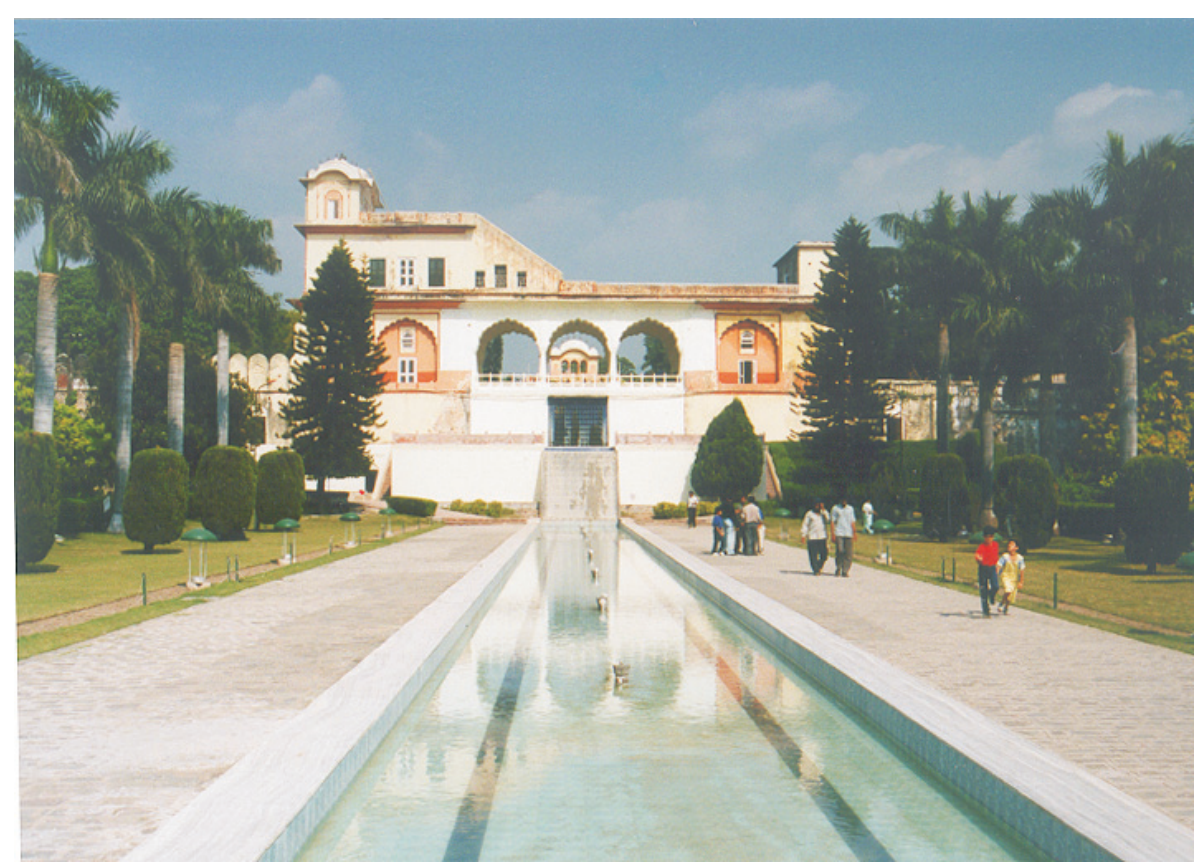

Figure 4. A view of active fault scarp now used as main step (Big Step) at the Mughal Garden in Pinjore town, near Chandigarh. The height of the scarp is about $12 \mathrm{~m}$. The garden was constructed across this scarp around $400 \mathrm{yr}$ ago.

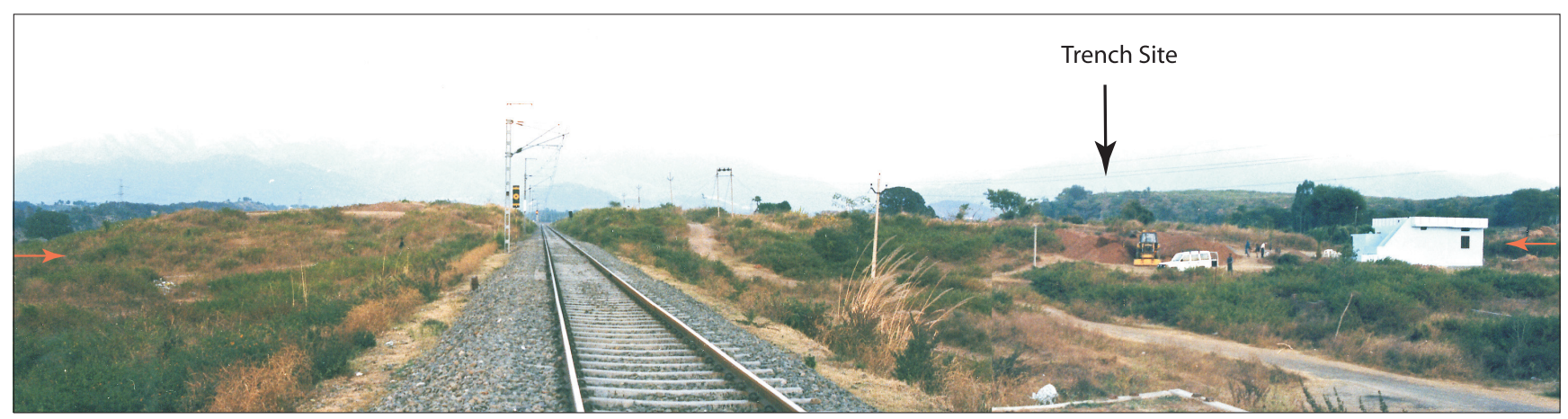

Figure 5. NNW-SSE striking fault scarp at village Ratpur along Pinjore Garden fault. Fault scarp (marked by red arrows) is about $6 \mathrm{~m}$ high. House in foreground is on footwall. The railway track cutting through the scarp is the Kalka-Simla mainline.

fault thus represents the younger imbricated fault which merges in the subsurface northward with the decollement. From its geographic location we are inclined to suggest that the PGF is a young imbricated fault of the MBT system. Such imbricate fault geometries are typical examples of the patterns seen in folds and thrust belts (Burbank and Reynolds 1988).

The present-day evidence of the intact masonry structure (big/main step) of the Mughal Garden at Pinjore is extremely noteworthy. There are no evidences or historic records which suggests that the garden was affected by any earthquake in the past. Considering this we suggest that, since the construction of this garden around $1600 \mathrm{AD}$, no major earthquake has struck this region and no major movements have occurred along PGF in the last 400 years. Detailed topographic profiling at Ratpur village using total station survey across the fault scarp shows a height of about $6 \mathrm{~m}$ from the base with two prominent breaks in the profile (figure 6). The break in the scarp profile is a clear indication that more than one earthquake has occurred along this fault (figure 6).

\section{Trench investigations}

A trench (15 m long, $4 \mathrm{~m}$ wide and 2-5 m deep) was excavated at Ratpur village across the NNW-SSE 


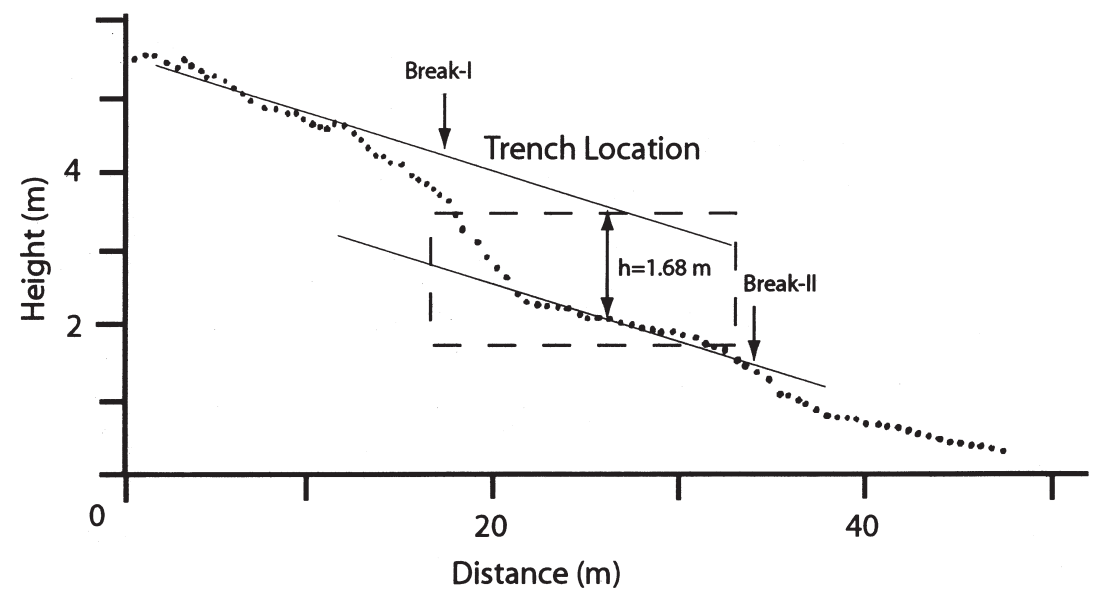

Figure 6. Topographic profile across the fault scarp at Ratpur. Dashed box marks the location of trench. Note that the relative height of the scarp is about $1.68 \mathrm{~m}$.

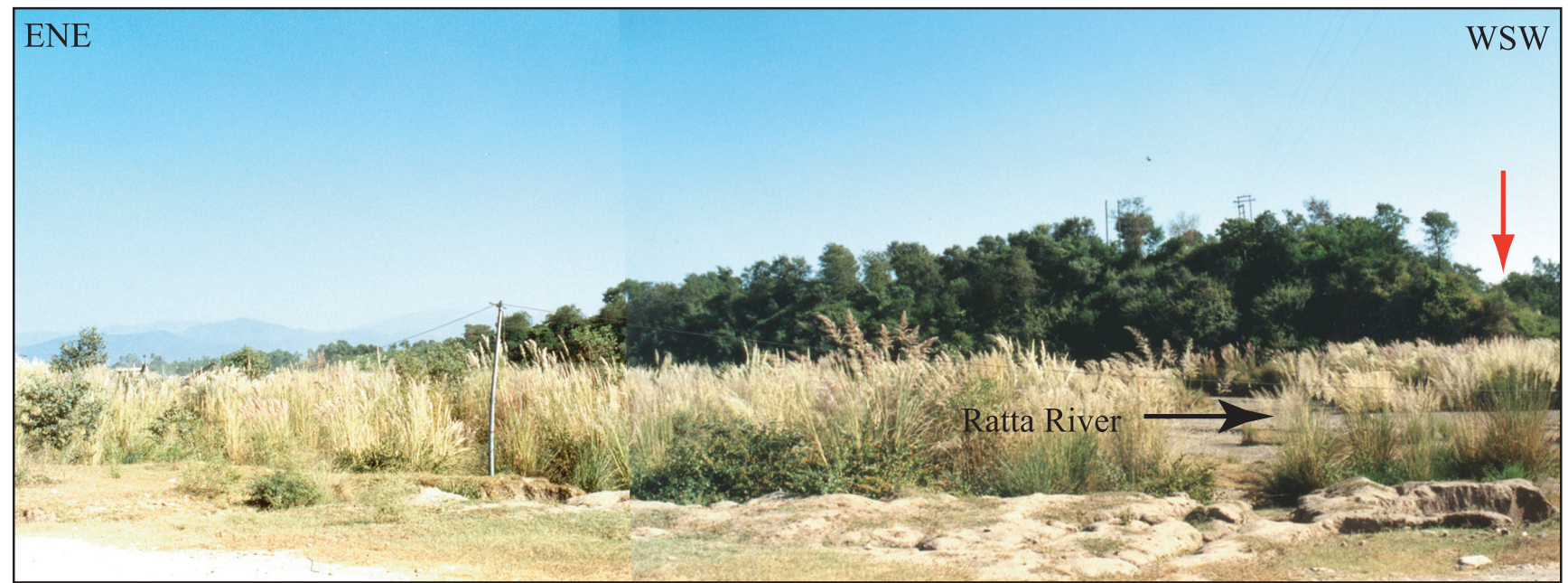

Figure 7. Faulted and back-tilted Pinjore surface at Makhu-Majra on the left bank of Ratta River. The tilt is about $6^{\circ}-7^{\circ}$ due northeast. Height of the fault scarp is about $8 \mathrm{~m}$ and decreases gradually upstream. Arrow indicates fault scarp (view looking southeast).

striking PGF (figures 2-6). The exposed sedimentary succession in the trench shows five prominent lithounits (figure $8 \mathrm{a}$ and $\mathrm{b}$ ). The units $\mathrm{A}$ and $\mathrm{C}$ represent channel-fill deposits, comprising moderately sorted matrix-supported pebblecobble-boulder clasts of sandstone from Lower Siwalik Formations. Unit A is overlain by dull brown (7.5 YR 5/4 as per Munsell Colour Chart) massive sand unit $B$. The unit $B$ shows erosive contact with the underlying unit A. In the upper section of the trench a more intense erosive contact can be seen, marked by small-scale troughs between unit $\mathrm{C}$ and unit $\mathrm{B}$ showing a concaveupward geometry. Unit D comprises medium to fine gravel overlying the unit $\mathrm{C}$ on the foot wall, however, no counterpart of this unit was observed in the hangingwall succession. Finally the succession on both sides of the fault is capped by the topsoil unit E.

A single thrust fault showing movement from NE to SW was identified on the north wall. This displaces A, B, C and D units (figure 8a and b). In clast-rich deposits the fault contact can be identified by a consistent clast fabric, which is different than that of the adjacent sedimentary strata/units. Shearing on the fault usually rotates the long axes of elongated gravels parallel to the fault plane resulting into a prominent fabric termed 'shear fabric' (McCalpin 1996). In the Pinjore trench, pebbles with their longer axes oriented parallel to the fault-plane contact were observed (figures $8 \mathrm{a}, \mathrm{b}$ and 9 ). Moreover, the depositional-erosional contacts developed between the respective lithounits are curved or concave-upward in geometry, suggesting 


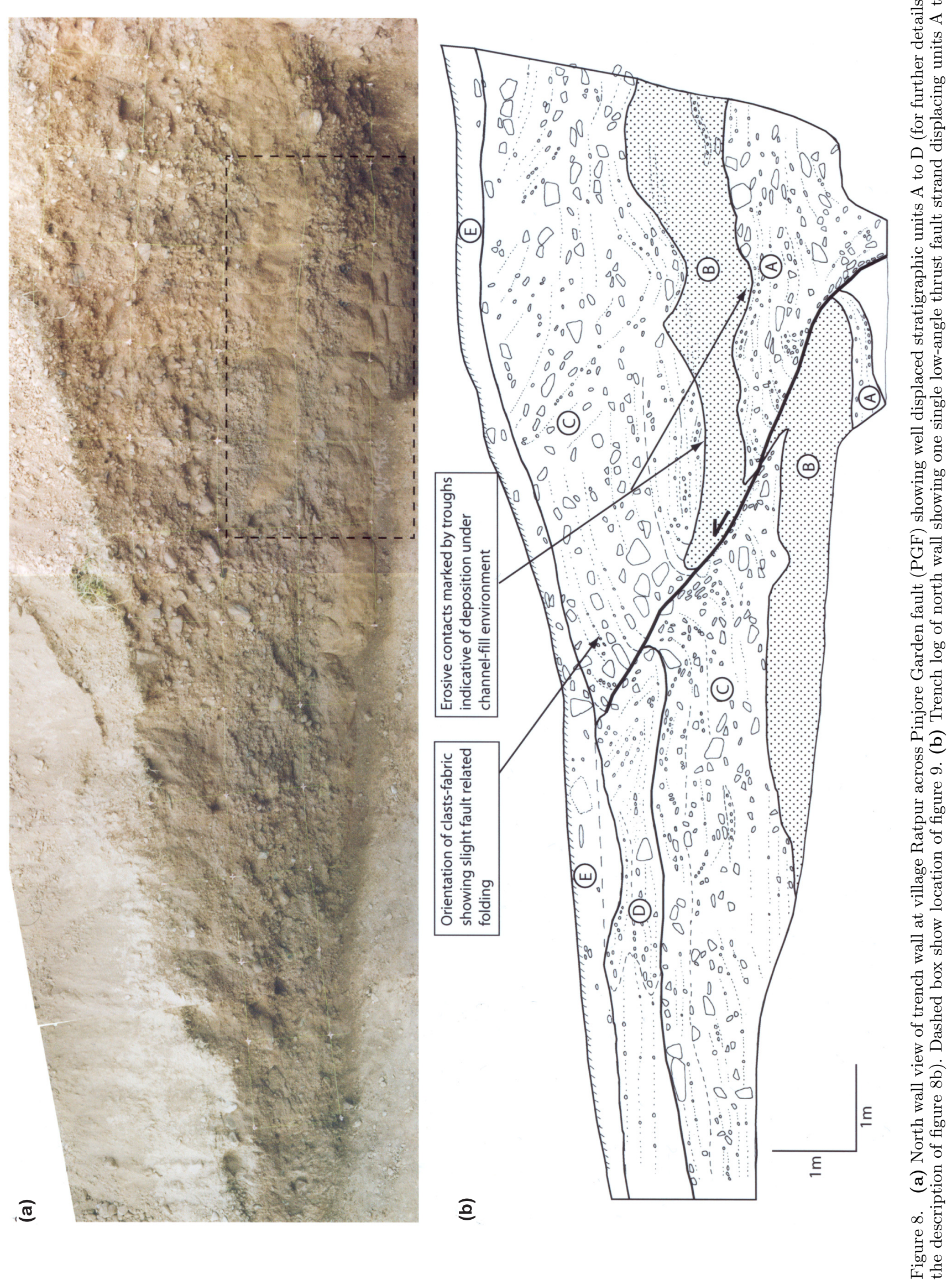




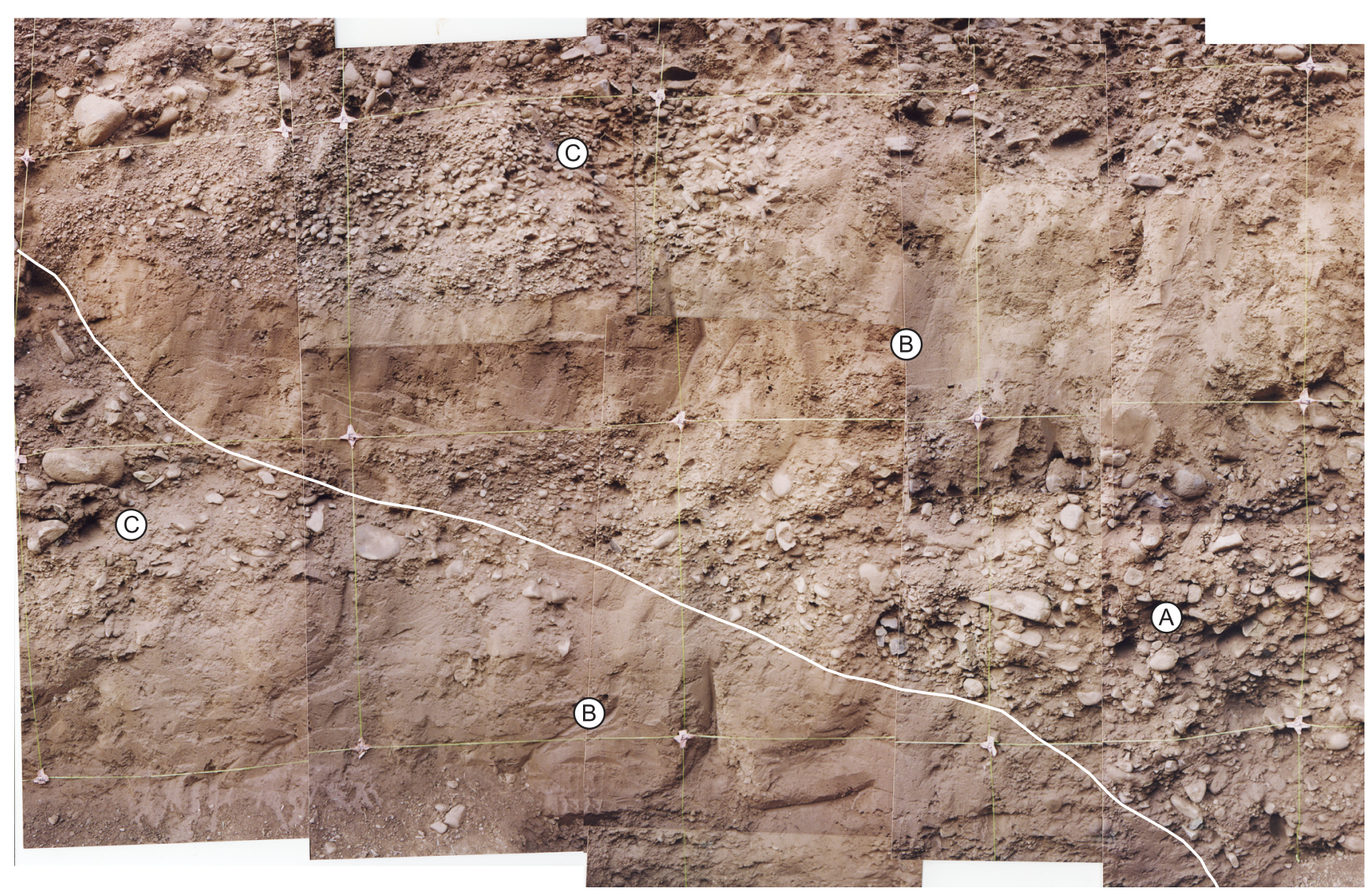

Figure 9. Close-up view of fault strand on north wall. White line marks the trace of the fault. Note the aligned gravel parallel to the fault plane. Scale - each square block is $1 \times 1 \mathrm{~m}$.

the contacts to be tectonic in origin. The movement along the fault has resulted in minor folding within the displaced units, which is well revealed by the internal arrangement of clast fabric (figures $8 \mathrm{~b}$ and 9 ). The fault is marked by variable dips ranging from $10^{\circ}$ to $49^{\circ}$ due E. Maximum dip $\sim 47^{\circ}-49^{\circ}$ was recorded in the lower portion of the trench where it has displaced the unit A, whereas in the central portion, the dip reduces to $10^{\circ}-17^{\circ}$, and near the surface the dip increases to $21^{\circ}$. It is difficult to explain the change in dip of the fault plane; however, it could be due to the fault plane passing through sediment successions having different grain sizes and shear strengths. The dip-slip movements $\left(T_{o}\right)$ measured in the trench suggests that the amount of $T_{o}$ is not constant between various lithounits. The basal unit A shows a maximum displacement of about $T_{o}=2.85 \mathrm{~m}$, unit $\mathrm{B}$ of $1.8 \mathrm{~m}$ and unit $\mathrm{C}$ of $1.45 \mathrm{~m}$ (figure $8 \mathrm{~b}$ ). Retro-deformation of the trench log was carried out wherein the displaced stratigraphic units were restored to their (inferred) original geometry. This helped us to understand the sequence of deformation/events along the PGF at Ratpur (figure 10). The sequence of displacement along the fault can be explained in five stages:
Stage I: The fault existed before the unit A was displaced.

Stage II: Event-I displaced unit A by $\sim 1.8-2 \mathrm{~m}$, followed by erosion of unit A and degradation of scarp near the toe on the hanging wall.

Stage III: Deposition of units B, C and D occurred under channel-fill environment. The deposition of these units is well marked by the erosive contacts and small troughs.

Stage IV: Event-II resulted into displacement of units $\mathrm{A}$ to $\mathrm{D}$ with displacement of about $\sim 1.8$ to $2 \mathrm{~m}$. The unit $\mathrm{A}$ was displaced for the second time, whereas the units $\mathrm{B}, \mathrm{C}$ and $\mathrm{D}$ for the first time. Here unit D is the event horizon.

Stage V: Degradation of scarp erosion of unit C partially and complete erosion of unit D on the hangingwall. This was followed by deposition of unit $\mathrm{E}$ (figures 8 and 10).

The colluvial wedge concept is one of the important criteria used to interpret the number of events in a trench investigation (McCalpin 1996). Since 

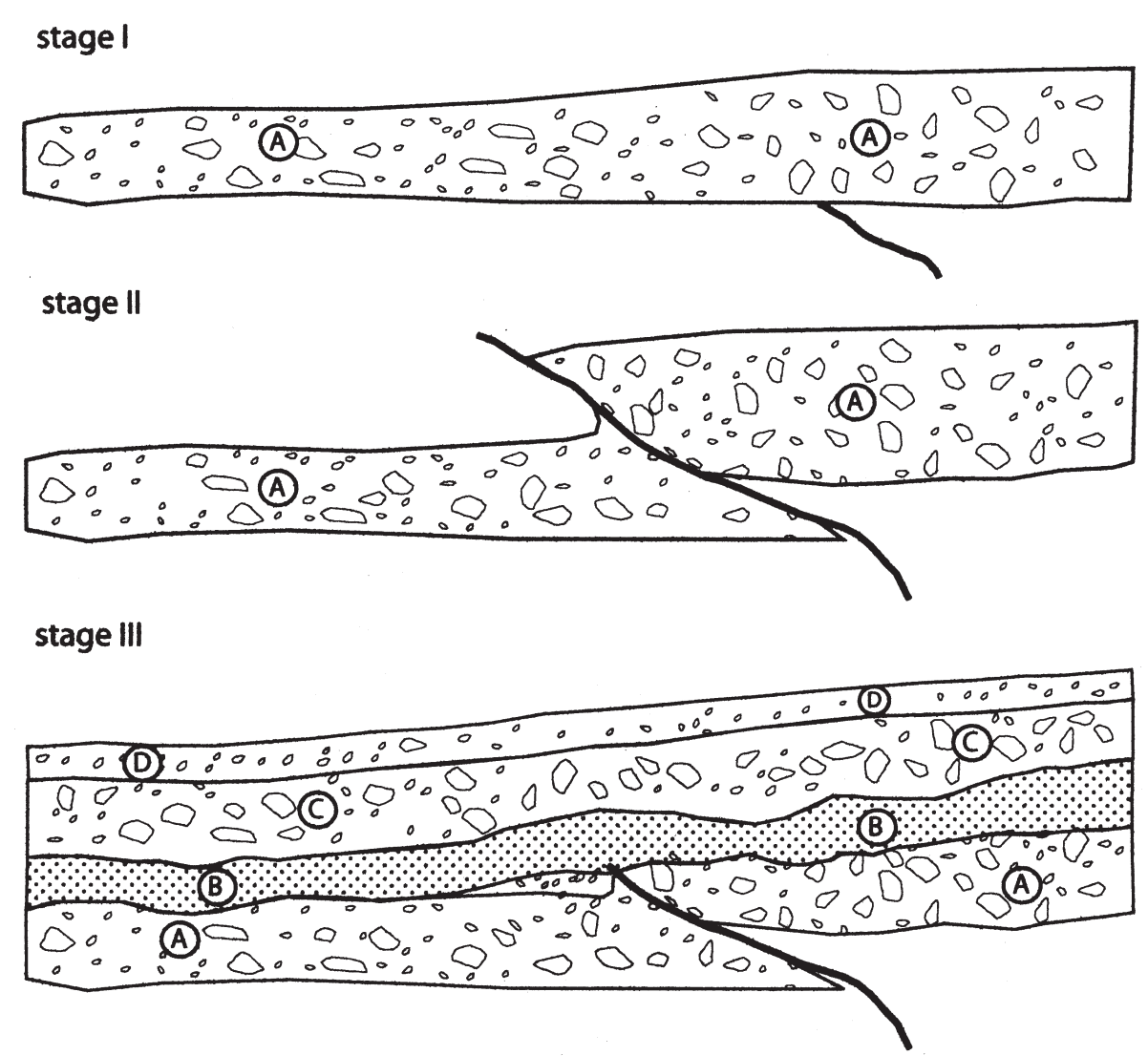

stage IV
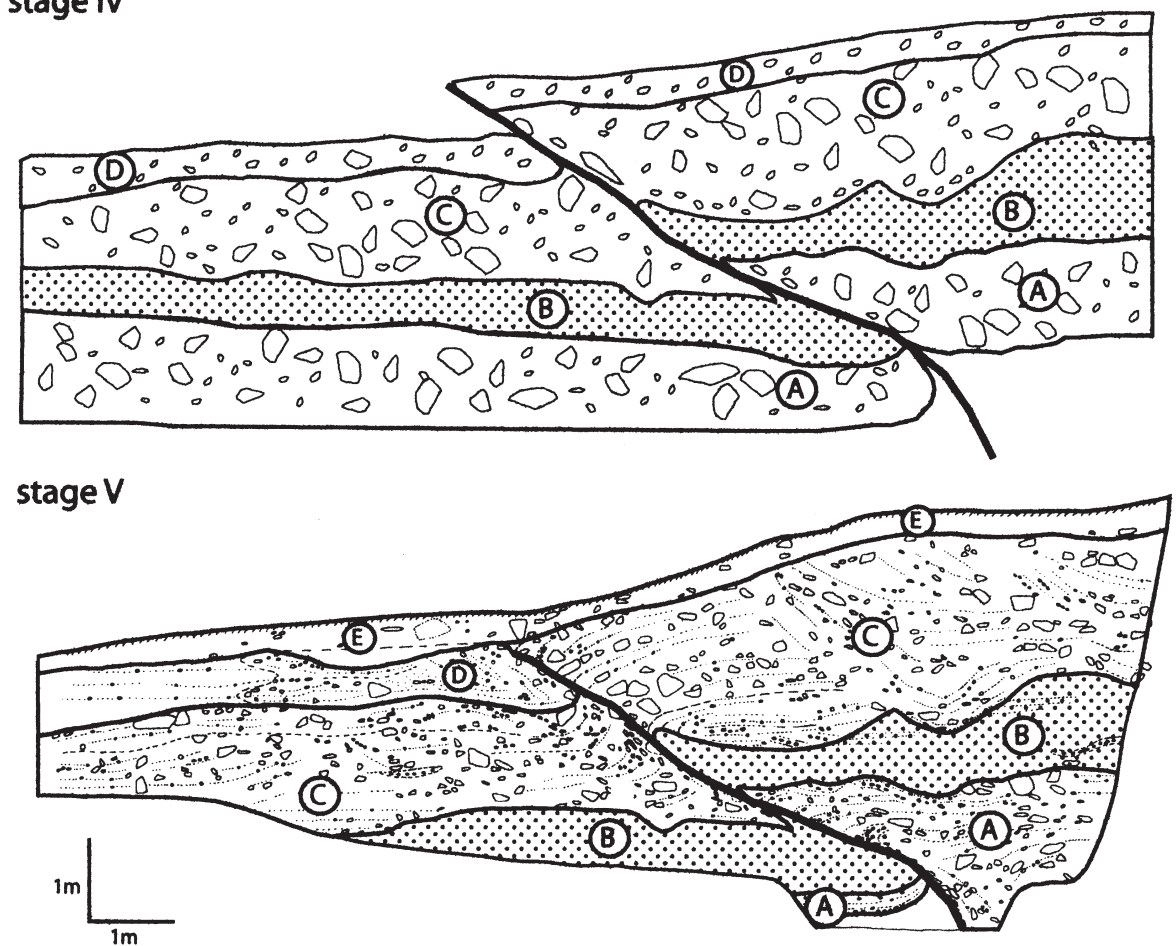

Figure 10. Schematic view of trench log showing sequence of faulting and depositional phases from Stage I to V.

our interpretation for both the event horizons (A and D) involves gravelly units, it was rather difficult to delineate a distinct contact between the normal deposits and colluvial material. Colluvial material is more distinct if the event takes place in a soil unit, where one can easily make out broken soil clasts in the wedge. It is suggested here that because the sediment succession is not very well 
sorted, chances of inter-mingling of colluvial material derived from the same gravelly unit is much higher.

An increase in the amount of displacement between various lithounits with depth was observed in the trench. This could be due to two factors:

(a) episodic faulting or

(b) attenuation of displacement in the vertical direction, however, the contributions of each of these factors is uncertain.

According to McCalpin (1996), to prove recurrent faulting, the displacements between the lithounits must abruptly increase with depth and the displacement within each unit must be constant. We infer that units $\mathrm{B}, \mathrm{C}$ and $\mathrm{D}$ displaced during the event-II registered the same amount of displacement. Later due to the partial erosion of unit $\mathrm{C}$ and complete erosion of unit $\mathrm{D}$, the amount of displacement we measured along unit $\mathrm{C}$ is indicative of the minimum displacement. Secondly, if the reduction in amount of displacement along the fault is due to the zeroing of the slip at the tip of the fault, then in such a situation the fault remains blind and the rupture does not reach the surface (McCalpin 1996; Outtani et al 1995). Since a clear displacement on the northern wall of the trench is seen, it is difficult to explain the reduction of amount of displacement due to simple attenuation of slip in a vertical direction. Thus the displacements measured between various sedimentary units, and retro-deformation of the trench log, together suggest at least two events to have occurred along the PGF at Ratpur, where $\mathrm{A}$ and $\mathrm{D}$ units mark the event horizons (figures 8 and 10).

If we take the value of $T_{o}$ measured from the trench along with various lithounits for calculating geometric parameters, with an average dip of the fault $\left(\theta=30^{\circ}\right)$, we get a vertical displacement $\left(V_{m}\right)$ for the unit $\mathrm{A}=1.43 \mathrm{~m}$, unit $\mathrm{B}=0.9 \mathrm{~m}$ and unit $\mathrm{C}=0.73 \mathrm{~m}$. The values of $V_{m}$ corresponding to units $\mathrm{A}$ and $\mathrm{B}$ are more or less consistent with the values measured from the trench, taking into account the top contacts of $\mathrm{A}$ and $\mathrm{B}$ units, where $V_{m}$ for the unit $\mathrm{A}=1.38 \mathrm{~m}$ and $\mathrm{B}=1.00 \mathrm{~m}$. But the value of $V_{m}$ obtained from the geometric calculation for unit $\mathrm{C}$ seems to be somewhat misleading, which may be due to:

(a) comparatively greater thickness of this unit on the hangingwall than on the footwall, and

(b) the absence of the counterpart of unit D on the hangingwall.

This makes measurement rather difficult. It is suggested that the near-doubling of the thickness of the unit $\mathrm{C}$ is probably due to lateral facies variations of channel-form. Therefore, with these restrictions, we prefer to consider the measurements obtained only from A and B units, which suggest at least two events, with a minimum displacement $\left(T_{o}\right)$ of about $1.05 \mathrm{~m}$ during each event. The cumulative displacement can be seen accommodated by unit $\mathrm{A}$ of about $2.85 \mathrm{~m}$.

The height of the Ratpur scarp is about $1.68 \mathrm{~m}$ (figure 6), which must have recorded at least two events; thus the total slip of about $3.28 \mathrm{~m}$ can be deciphered in the stratigraphic succession exposed in the trench along unit $\mathrm{A}$, which was displaced twice. However, the net displacement measured along the unit A is much less $(2.85 \mathrm{~m})$. This gives the minimum cumulative slip during two events and possibly during the phase of unit $\mathrm{B}$ deposition, some part of unit A might have eroded leading to less vertical offset preserved in the stratigraphy. Even the $1.8 \mathrm{~m}$ of slip along unit $\mathrm{B}$ is an indication of minimum slip; therefore, at least $1.8-2 \mathrm{~m}$ of slip must have occurred during each event.

In the trench the south wall displays a totally different deformational structure from the north wall. The south wall exhibits well developed fault-related folding (figure 11a and b). Minor fault-related folding can be seen on the north wall section, but is not as prominent as seen on the south wall. In comparison to the north wall, it was difficult to trace the fault passing through deformed A, B and $\mathrm{C}$ units in the south wall. The fault-related folding has resulted into doubling of the thickness of units $\mathrm{B}$ and $\mathrm{C}$. There are two possibilities for the fault trace; either it passes through all the units where the warping of the layers ends (axes of all folded beds), or the fault follows the interbed contact between the unit $\mathrm{A}$ and overlying B unit. Suppe and Medwedeff (1990) and Outtani et al (1995) have documented that during folding related to faulting, fault propagation might stop and the displacement may be transferred either to another site or through the fold itself, or the next faulting event may result into the break-through within the forelimb. The deformational features observed in the trench suggest that both the north wall and south wall exhibit the phenomenon of fault-related folding. But the north wall shows break-through marked by the displaced stratigraphic units, whereas the south wall shows clear evidence of fault-propagated folding. It is rather difficult to explain the variation in deformation observed on the north and south walls. However, it has been suggested that in thrust faulting environment, due to the complex interaction of faulting and folding, and due to changes in amount of slip and dip of fault, the pattern of deformation and related surface displacements are 

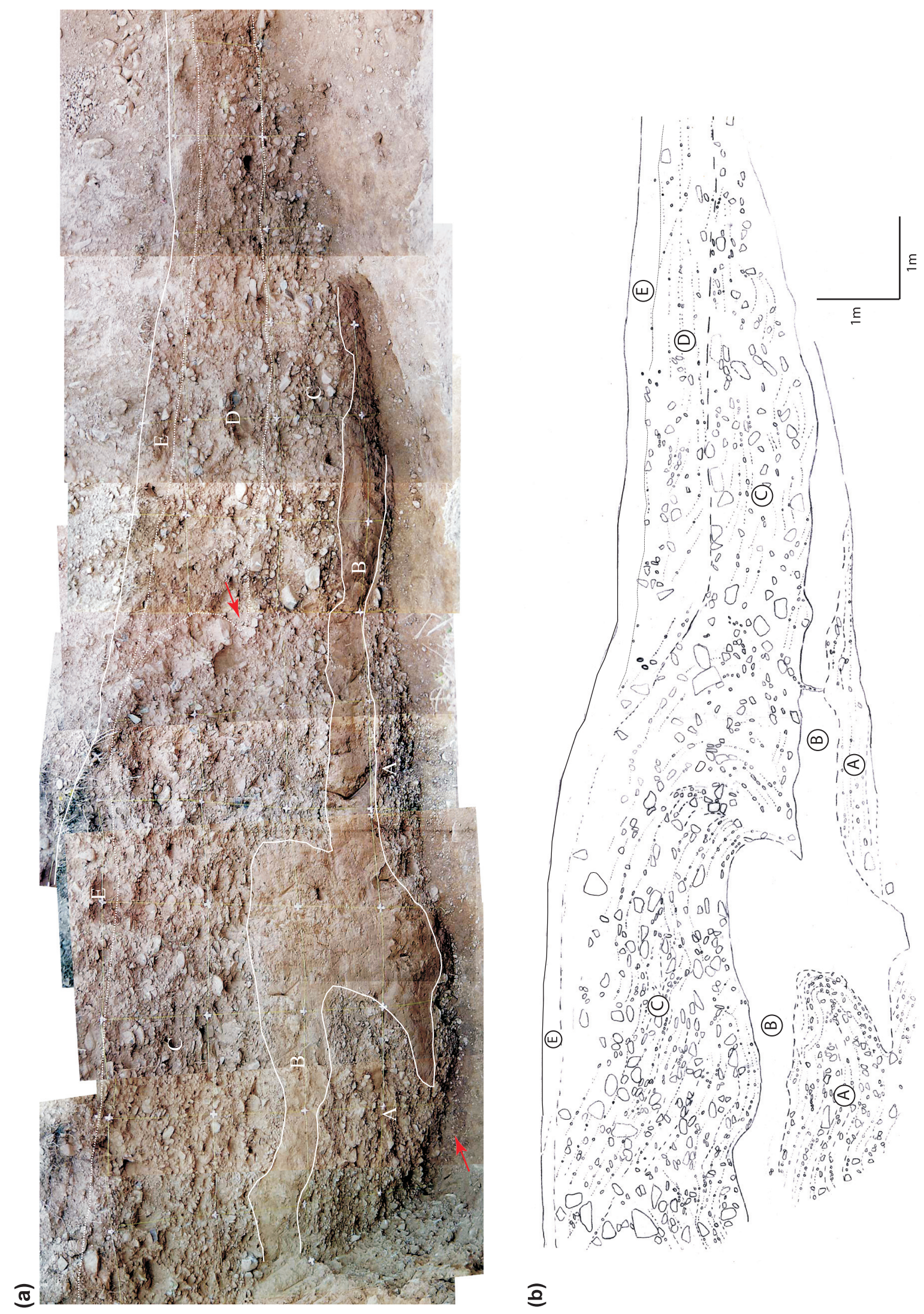

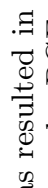

올 으

: :

옹 요

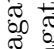

율

莺壱

를

章总

绨它

ॠ

कี.

客

๘)

일

సٓ.

龸范

ㄷ.

赵

융.

궁

蛋

उ

웡횽

㟧

궁

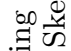

อ

둥

苞

虫

总青节

壳焉

艿娄范

푱

की

(⿶)

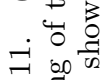

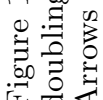


irregular along the strike (McCalpin 1996). We therefore suggest that the variation in deformation is possibly due to change in fault dip in a short distance of $3.5 \mathrm{~m}$.

\section{Discussion and Conclusions}

The Himalaya being one of the most seismically active regions, its seismic hazard assessment is a key issue to be addressed correctly. The present study indicates that for the evaluation of seismic hazard in the Himalayan region it is necessary to carry out investigations along all faults which show prominent geomorphic evidence of current activity. This is essentially because the overall picture of slip distribution across the Himalaya, which is suggested to be about $20 \mathrm{~mm} / \mathrm{yr}$ (Bilham et al 2001), will only be effective when we know the slip rates along individual active faults in the region. The active faults identified by Malik and Nakata (2003) are distributed in a $16-25 \mathrm{~km}$ wide zone, where the PGF is located about $10 \mathrm{~km}$ north of the HFF. Therefore, along with the HFF, other inland active faults to the north need equal attention and detailed study.

Apart from the active tectonic signatures, evidence for displaced young alluvial fan surfaces in the Pinjore Dun clearly points towards the recent seismic activity along the PGF. The active fault trace (PGF) represents the young imbricate fault of the MBT system, which merges in the subsurface northward with the decollement. This type of geometry and pattern of faulting is commonly seen in fold-and-thrust belts (Burbank and Reynolds 1988) and is associated with thrusts that normally step up in the direction of slip to a higher decollement, or a ramp in a decollement resulting in faultpropagated folding as defined by Suppe (1983). The intact masonry structure of the Mughal Garden at Pinjore which was $\sim 1600 \mathrm{AD}$ suggests that no major movements have occurred along the PGF in the last 400 years (Malik and Nakata 2003). Therefore, it is logical to presume that the recurrence interval in this region along the PGF is greater than 400 years. It is suggested that strain is building along this fault for a potentially high-risk large magnitude earthquake in the future.

The active fault traces displacing the older (Kalka) as well as younger (Pinjore) surfaces suggest that the PGF system has remained active since its formation. The less dissected morphology of the faulted Pinjore surface at Ratpur indicates that this surface was probably formed during the late Holocene. The geometry of deformed surfaces near the fault line is indicative of movement along a low-angle thrust fault dipping northeast, and the pattern of deformation is similar to that observed in the himalayan frontal portion along the Chandigarh fault (Malik and Nakata 2003).

Preliminary trench investigation along the PGF reveals that at least two events have occurred along a single low-angle thrust fault $\left(\sim 30^{\circ}\right)$ during the recent past. This can be well constrained by the variable amount of displacement recorded in the trench, where the basal unit A shows maximum displacement $\left(T_{o}\right)$ of about $2.85 \mathrm{~m}$, unit $\mathrm{B}$ of $1.8 \mathrm{~m}$ and unit $\mathrm{C}$ of $1.45 \mathrm{~m}$ (figure $6 \mathrm{a}$ and $\mathrm{b}$ ). This suggests that the unit $\mathrm{A}$ has been displaced twice during the respective individual event. The $T_{o}$ observed for the units $\mathrm{A}$ and $\mathrm{C}$ are the lower bound values, hence it is suggested that at least $1.8-2 \mathrm{~m}$ of slip must have occurred during each event.

The pattern of deformation and style of faulting identified by us is very much similar to that recorded from trenches along low-angle thrust faults in Algeria (El-Asnam fault; Meghraoui et al 1988) and in the Himalaya (Chandigarh fault; Malik et al 2003). The difference in deformational features displayed by the north wall and south wall is due to the sudden change in the fault dip along its strike. The evidence of fault-related folding on the south wall is manifested on the surface with the reduction of scarp height towards the southern side of the fault trace. The amount of average displacement $(2 \mathrm{~m})$ during each individual event observed on the north wall of the trench and the minimum cumulative length of the fault trace $(\sim 45 \mathrm{~km})$ suggest that the PGF is capable of producing large magnitude earthquakes, like the HFF. Therefore, detailed paleoseismic investigations are warranted along the PGF, the inland active faults, as well as the HFF.

\section{Acknowledgements}

We are thankful to Prof. R V Karanth and two anonymous referees for critical comments and suggestions which enormously helped us in improving our manuscript. JNM is thankful to the Department of Science and Technology, New Delhi for providing financial support (vide project No. SR/FTP/ES-46/2001), to Prof. M Meghroaui (Institute de Physique de Globe de Strasbourg, France) for providing valuable discussions and suggestions during this study and to Prof. T Nakata, (Hiroshima University, Japan) for creating interest to work in this area. This work was carried out when GM was a post-doctoral researcher with Prof. A K Singhvi at PRL, Ahmedabad.

\section{References}

Ambraseys N and Bilham R 2000 A note on the Kangra Ms $=7.8$ earthquake of 4 April 1905; Curr. Sci. 79 45-50. 
Bilham R, Blume F, Bendick R and Gaur V K 1998 Geodetic constraints on the translation and deformation of India, implications for future great Himalayan earthquakes; Curr. Sci. 74 213-229.

Bilham R, Gaur V K and Molnar P 2001 Himalayan Seismic Hazard; Science 293 1442-1444.

Burbank D W and Reynolds R G H 1988 Stratigraphic keys to the timing of thrusting in terrestrial foreland basins: Applications to the northwestern Himalaya; In: New Prospective in basin analysis: Kleinspehn K L and Paola C (eds) (New York: Springer-Verlag), Pp. 331-351.

Khattri K N and Tyagi A K 1983 Seismicity patterns in the Himalayan plate boundary and identification of areas of high seismic potential; Tectonophys. 96 281-297.

Kumar S, Wesnosusky W G, Rockwell T K, Ragona D, Thakur V C and Seitz G G 2001 Earthquake Recurrence and Rupture Dynamics of Himalayan Frontal Thrust, India; Science 294 2328-2331.

Malik J N and Nakata T 2003 Active faults and related Late Quaternary deformation along the northwestern Himalayan Frontal Zone, India; Anna. Geophys. 46 917-936.

Malik J N, Nakata T, Philip G and Virdi N S 2003 Preliminary observations from trench near Chandigarh, NW Himalaya and their bearing on active faulting; Curr. Sci. 85 1793-1799.

McCalpin J P 1996 Paleoseismology; Academic Press, New York, p. 588.

Meghraoui M, Philip H, Albarede F and Cisternas A 1988 Trench investigations through the trace of the $1980 \mathrm{El}$ Asnam Thrust Fault: Evidence for paleoseismicity; Bull. Seism. Soc. Am. 78 979-999.

Nakata T 1989 Active faults of the Himalaya of India and Nepal; Geol. Soc. Am., Sp. Pap. 232 243-264.
Oatney E M, Virdi N S and Yeats R S 2001 Contribution of Trans-Yamuna Active Fault System towards Hanging wall strain release above the décollement, Himalayan Foothills of Northwest India; Him. Geol. 22 9-27.

Ori G and Frined P F 1984 Sedimentary basins formed and carried piggyback on active thrust sheets; Geology 12 $475-478$

Outtani F, Addoum B, Mercier E, Lamotte D and Andrieux J 1995 Geometry and kinematics of the South Atlas Front, Algeria and Tunisia; Tectonophys. 249 233-248.

Philip H, Rogozhin E, Cisternas A, Bousquet J C, Borisov B and Karakhanian A 1992 The Armenian earthquake of 1988 December 7; faulting and folding, neotectonics and paleoseismicity; Geophys. Int. 110 141-158.

Seeber L and Armbruster J G 1981 Great detachment earthquakes along the Himalayan arc and long-term forecasting; In: Earthquake Prediction - An international Review, Simpson D W and Richards P G (eds) AGU. 259-279.

Suppe J 1983 Geometry and kinematics of fault-bend folding; Am. J. Sci. 283 684-721.

Suppe J and Medwedeff D A 1990 Geometry and kinematics of fault-propagation folding; Ecologae Geol. Helv. $\mathbf{8 3}$ 409-454.

Valdiya K S 2001 Reactivation of terrain-defining boundary thrusts in central sector of the Himalaya: Implications; Curr. Sci. 81 1418-1431.

Yeats R S and Thakur V C 1998 Reassessment of earthquake hazard based on a fault-bend fold model of the Himalayan plate-boundary fault; Curr. Sci. 74 230-233.

Yeats R S, Sieh K and Allen C R 1997. Geology of Earthquakes; Oxford Univ. Press, p. 568. 